\title{
Factors Contributing to Teachers' Resistence in Integrating ICT in EFL Classroom in Senior High School
}

\author{
Nur Kamilah \& Mirjam Anugerahwati \\ Universitas Negeri Malang \\ (k4m1lah@gmail.com \& mirjamanugerahwati@yahoo.com)
}

\begin{abstract}
ICT has become powerful media for teaching English, especially in improving students' learning autonomy. However, studies have revealed that English teachers are sometimes resistant to ICT integration in the class, in which the resistance fails the effective ICT integration. The purpose of this study is to explain English teachers' resistance towards ICT integration in the class by presenting and the categories of the resistance. There were seven teachers from six different senior high schools investigated in this study. Using semi-guided interview, observation and documentation, the study yielded the findings. There were three categories of resistance found; extreme, moderate and zero resistance. The factors contributing to the resistance were coming from external and internal, such as the unwillingness to learn and use ICT, lack of ICT competence and pedagogical knowledge, concerns about ICT for students, and unsupportive school facilities. It was also found that age might not matter much in contributing to the resistance and that the teachers' perception is not always reflected in their teaching practice.
\end{abstract}

Keywords: ICT integration, teacher's resistance, factors of resistance, category of resistance.

Information and Communication Technology (ICT) refers to some products of communication technology, like hardware (i.e. computers, mobile phones, projector, radio, TV), the software application (i.e. multimedia sources, communication application), and the information system (i.e. the Internet, Intranet, cloud computing) (Hennessy, Ruthven, \& Brindley, 2005; Raval, 2014; Tinio, 2003). ICT is an integral part in the 21 st century learning. It has been mentioned in " 21 st Century Skills for Students and Teachers" (2007) that there are four learning and innovation skills used as the standard for the 21st century learning, well-known as the $4 \mathrm{C}$ 's, which are critical thinking, communication, collaboration, and creativity. In achieving each of the skills, integrating ICT in teaching and learning in every subject matter is important, not to mention in English as a foreign language (EFL). ICT is considered as having the capability to facilitate the achievement of the $21 \mathrm{st}$ century skills. Particularly, ICT in ELT has been regarded such a powerful media that it offers opportunities in enhancing teaching and learning process.

The current trend of English Language Teaching (ELT) emphasizes learning in learners (Kumaravadivelu, 2003). Following the theory of Second Language Acquisition (SLA), language learning should enhance the learning and acquisition of a language, as 
hypothesized by Krashen (2003). Learning happens in the language classroom and it is delivered through specific English instruction, whereas acquisition happens in an interaction which features the meaningful use of the target language thus this interaction enables learners to acquire the language (Saville-Troike, 2006), or it is what Krashen (2003) means as a subconscious process of learning. This theory inspires language teachers to expose more authentic and meaningful interaction in the target language so that learners will have more opportunities to use the language they learn in the class. Besides, language learning also encourages teachers to understand learner's differences which include motivation, aptitude, needs, learning style, and strategy (SavilleTroike, 2006). Being aware of and appreciating the learner's differences will make the students more motivated and interested in learning English because the language learning will weigh more on the learners. The students' motivation and interest in learning English will make the achievement of the learning goals easier to accomplish because they will actively participate in achieving them. Thus, the shared goal of learning in ELT and the curriculum should make English teachers focus on shaping learners to be more independent learners.

In fact, some studies have proven that using ICT in ELT is advantageous in achieving the aims of English language teaching. Firstly, from the student's perspective, in a study by Young (2003), the students found the Internet an interactive and useful tool for learning English. In more detailed findings, Hashemyolia and Ayub (2014) researched the effect of a multimedia based courseware named Rosetta Stone's English Language Courseware (RSELC) to EFL learners and found that using it made them understand text better. They conclude that learning English by using this courseware makes learning more authentic because it exposes learners to real activities of using, for instance, grammar. ICT has also been proven beneficial to promote intercultural interaction among EFL learners and the people of the target culture, like using Facebook and YouTube videos (Benson, 2015; Jin, 2015). In addition, Çelik, Arkın, and Sabriler (2012) investigated students' self regulated learning. They found that ICT is used consistently by EFL learners as a tool to help achieve their learning goals. In improving language skills, ICT has mostly been used for practicing listening, followed by enriching vocabulary and practicing writing. The least usage of ICT is for practicing speaking, reading and grammar. More students practice their language skills by surfing websites on the Internet and also using English audios and videos from the YouTube and from their own inventories.

Studies have also identified different responses from teachers as ICT is used in ELT. Cahyani and Cahyono (Cahyani \& Cahyono) studied English teachers' attitude towards ICT and found that they were helped in making teaching and learning 'more practical, efficient, and effective', because using ICT eased them when providing the authentic models of the target language. They also could feel that the students were better managed because they were more interested in learning thus the learning goals were easier to achieve. Additionally, Tapaliya (2014) researched teachers' perception towards their practice of using ICT in Kathmandu, Nepal and found that the various types are used in order to arouse "students' motivation, ... gain understanding and analytical skills, ... build self-confidence and self-esteem, and provide reliable and authentic materials." On the other hand, English teachers have also been found resisting ICT integration in EFL classroom. Salehi and Salehi (2012) reveal that although most of the teachers have used ICT in their daily lives (70\%), $76.6 \%$ of them admit that they never use ICT for teaching ELT or use it very little. Therefore, even though the teachers are familiar with ICT, they are discouraged to use it for teaching and learning. Nair et al., (Nair et al.) also have found that the group of old teachers, ranging from 41 to 50 years old, has shown lesser frequency of ICT use in their teaching. 
Resisting ICT or being discouraged to integrate ICT into ELT when it has been found very supportive in achieving the learning aims feels like wasting a good opportunity. Resistance is 'unwillingness or refusal or reluctance to adopt ICT (Harendita, 2013). EFL teachers with this attitude are considered to be the ones who cause failure in ICT integration, mainly because it is related with their belief that using ICT in EFL classroom will not significantly benefit the EFL classroom. It is supported by the four critical areas in technology integration for creating a successful transform teaching and maximizing benefits of the technology (National Educational Technology Trends, 2012 as cited in Hanover Research, 2014). They are infrastructure, educator effectiveness, innovative learning models, and college and career preparation. This implies that despite the support from the school to provide adequate technologies for the teachers, the ICT integration in ELT will fail unless the teachers effectively use it in their teaching instruction.

Resistance can be caused by several factors hindering the teachers from using ICT more optimally. In this paper, there are two categories of factors, such as external and internal factors. The external factors refer to those occurring outside of the teacher, whereas the internal factors deal with those occurring inside of the teacher. The factors have been investigated and have shown consistent results, as discussed in the following. First, there are several factors classified as external factors against teachers' use of ICT in ELT classroom. To begin with, Bingimlas (2009) states that the lack of effective training to teachers for the use of ICT in classroom may be the main barrier. Effective training is that which provides adequate knowledge of ICT and pedagogical knowledge of how ICT is used for education or teaching in the classroom and adequate time for training which encompasses enough training for the teachers' practice of using ICT for teaching. Consequently, the lack of effective training provided to teachers would result in the lack of competence. Moreover, teachers' training needs to indoctrinate them in order to be willing to use ICT in their classroom and confident that ICT will benefit their students.

Besides the lack of effective training, the lack of technical supports like the accessibility to ICT is equally influencing the teachers' use of ICT. Teachers think that this is tiresome when they have to book ICTs like projectors and that they cannot use them for several meetings in a row, for other teachers are using them as well. Statistically, Salehi and Salehi (2012) found that the most discouraging factor to the use of ICT in EFL classroom is the few ICT technical supports at school. It is followed by the little access to the Internet and ICT, shortage of class time as well as time needed by the teachers to learn how to integrate ICT in their classroom. Indeed, such aforementioned factors make the teachers feel hindered, thus, they become reluctant and resistant to integrate ICT in their ELT classrooms. This is in line with the findings of Rababah, Melhem, Jdaitawi, Rababah, and Rababah (2012) that state the lack of support and resources as one of the factors hampering the teachers' integration of ICT. They agree that teachers have to be adequately supported so that the teachers can be more encouraged to integrate ICT into their teaching practices.

Several internal factors are also identified in the teachers' resistance when using ICT as the learning media in the EFL classroom. Williams and Burden (1997) contend that in order to construct effective teaching in language learning, it is important to evaluate what beliefs the teachers bring to their classroom. Indeed, the teacher's beliefs in teaching and learning a foreign language will be defined in the learning activities they present, not to mention when using ICT. Additionally, Williams and Burden suggest that beliefs brought by teachers to the classroom will influence their way of planning lessons, making decisions, and arranging other general classroom practices, even greater than their knowledge will do (Williams \& Burden). Empirically, this is supported by Salehi and 
Salehi (Salehi \& Salehi). They review literature about beliefs and how these might influence teachers' attitudes towards ICT use in the classroom, which in turn will lead them to the decision whether to accept or resist the innovative change to their classroom. Similarly, Varank and Tozoglu (2006) state that the teacher's belief about ICT will likely determine their attitudes towards its integration in education. They might think it as a complicated tool that frightens them. It is apparent that their efforts to integrate ICT in teaching and learning activities are hampered by the negative beliefs towards it.

Another potential factor to teachers' resistance towards ICT use in the classroom is the lack of competence, both pedagogical and IT competence. This lack of competence was studied by many researchers, like Nair et al. (2012). They found that there is a significant difference between the teacher's age and their attitudes towards the use of ICT in foreign language teaching; the older the teacher, the less likely they use ICT for teaching. An assertion was added to the findings that the older the teacher, the lesser competence of integrating ICT in teaching they have, which implies the need for more teacher training focusing on not only the basic ICT skills but also pedagogical aspects of ICT so that they have the knowledge to develop the use of ICT in order to suit their teaching and learning environment. The lack of competence also contributes to the lack of confidence, as mentioned in Bingimlas (2009) that the limitations of the teacher's knowledge in ICT make them not confident in using it in their classroom; they are afraid of making technical mistakes.

Furthermore, several studies attempt to describe and classify several dilemmas which occur in teachers who resist the use of ICT in their classroom (Harendita, 2013; Orlando, 2014). They are conceptual, pedagogical, cultural, and political dilemma. Conceptual dilemmas are the attempt to understand philosophical, psychological and epistemological underpinnings of the change in the newly context, which is the use of ICT for teaching. Secondly, the pedagogical dilemmas come when the teachers design the curriculum using more complex approaches and design the learning experience for the students in the classroom, especially when they need to adjust ICT in the curriculum and the classroom practice. Meanwhile, the cultural dilemmas arise between teachers and students during the roles in the teaching and learning in the classroom; for example, the roles of teacher and student in traditional classes in Indonesia that may be analogized as jars and mugs (Mokoginta, 2013). Jars and mugs are an analogy for teacher and student, in which a teacher is considered as a jar who is the only source of knowledge or the only knowledgeable person in the teaching and learning environment. Meanwhile, mug is the analogy for student who will be filled by the knowledge from the jar. Such jars and mugs are mostly found in teacher centered way of teaching, in which the teacher dominates the class by explanations and provides the materials for the students. Finally, the political dilemmas occur when the teachers' routine of privilege and authority are disturbed, especially by the authorities or stakeholders. To these dilemmas, both Harendita (2013) and Orlando (2014) agree that the cultural dilemmas appear to be one of the most obstructing factors because there is a shift in the teacher's paradigm regarding their role as the central of knowledge in the classroom which had been built from the more teacher-centered to student-centered. Therefore, as the teachers may feel that their roles in the classroom are threatened, they would prefer not using ICT in their teaching intensely.

Additionally, a study by Nair et al., (Nair et al.) has detected differences between the group of old (41-50) and young (20-30) teachers in their use of ICT in their classes. The study shows that the older teachers use ICT lesser than the younger ones. The factor of age is further related to the assumption that the older teachers are less competent than the 
Table 1. Summary of the Factors InfluencingTeacher's Resistance in the Integration of ICT in ELT

\begin{tabular}{|c|c|c|}
\hline External Factors & $\begin{array}{l}\text { Lack of effective teacher } \\
\text { training } \\
\text { Lack of technical sup- } \\
\text { ports provided for the } \\
\text { teachers }\end{array}$ & $\begin{array}{l}\text { Bingimlas (Bingimlas), } \\
\text { Nair et al., (Nair et al.) } \\
\text { Salehi and Salehi (Salehi } \\
\text { \& Salehi), Rababah et al., } \\
\text { (Rababah et al.) }\end{array}$ \\
\hline Internal Factors & $\begin{array}{l}\text { - Teachers' beliefs towards } \\
\text { the use of ICT in EFL } \\
\text { classroom } \\
\text { - Lack of teachers' ICT } \\
\text { competence } \\
\text { - Lack of teachers' ped- } \\
\text { agogic competence } \\
\text { related to the use of ICT } \\
\text { in ELT } \\
\text { Cultural dilemma } \\
\text { regarding the shift of } \\
\text { teacher's role in the class }\end{array}$ & $\begin{array}{l}\text { - Salehi and Salehi (Salehi } \\
\text { \& Salehi) } \\
\text { - Nair et al., (Nair et al.), } \\
\text { Bingimlas (Bingimlas), } \\
\text { Harendita (Harendita) } \\
\text { - Orlando (Orlando), Har- } \\
\text { endita (2014) } \\
\text { - Mokoginta (Mokoginta), } \\
\text { Orlando (2014), Haren- } \\
\text { dita (2014) }\end{array}$ \\
\hline
\end{tabular}

younger ones, therefore the older ones might need more ICT trainings or workshops to enhance their ICT skills and knowledge for teaching purposes. According to Steadley (2006), Generation X, those who were born in the 1960s, are also the digital immigrants. The technology entered later in their life than Generation $\mathrm{Y}$ and $\mathrm{Z}$. This makes them naturally slow learners and slow users of the technology. Steadley also mentions that they can become a challenge for this globalized era. Apparently, such analysis on the generation has made the findings that age is a factor influencing resistance is less significant because it seems obvious that the older teachers (especially those who are in a different generation from the younger ones) are less familiar and competent in ICT technologies than the younger teachers. Therefore, the factor of age is less taken into account in this study. Table 1 presents the summary of the factors influencing teachers' resistance to the integration of ICT in ELT which are considered in this paper.
To put it in a nutshell, teachers can be resistant to ICT integration in ELT due to many influential factors. Being resistant to ICT integration can fail the implementation of ICT in the class, whereas ICT has been known for its benefits in English language teaching. Several researchers have previously investigated the factors of resistance and have identified that resistance may be caused by external and internal factors. Each of the factors has its own role of contribution but it should not be taken for granted. Revealing and understanding the factors should encourage teachers to adopt more ICT technologies in their classes so that the integration can be more successful. However, before considering improving the teachers' attitude of integrating ICT in the class, it is vital to take into account the degree of their resistance. For example, when teachers are resistant in a way that they are totally closing themselves from using ICT, there should be a or some severe factor(Young) to this, like their negative beliefs to ICT. It is different from the 
teachers who are resistant in a way that they are using ICT but not very maximally due to the inadequate support of technologies. To the two cases, the attempt to deal with the resistance should be different. When an attempt is made by supplying more technology supports to the school to the teachers, the resistance of the latter teachers may be dealt well, but that of the former teachers may fail. To fill in these gaps of teachers' resistance in ICT integration in ELT, this study was aimed at categorizing the teachers based on the degree of their resistance and present the factors based on degree of resistance of the investigated teachers.

\section{Method}

Aiming at explaining why teachers resist to ICT integration in EFL classroom in high schools in Situbondo, qualitative approach was used, particularly a case study. Several teachers as the subjects of the study are teaching in different schools that allowed the researcher to gather the information from multiple sites. In this regard, the design administered for the present study was a multi-site case study. Bogdan and Biklen (1992) define multi-site study as a study which involves many sites and subjects, rather than two or three.

The research sites were six senior high schools selected of 16 in total, namely SMAN 1 Situbondo, SMAN 2 Situbondo, SMAN 1 Suboh, SMAN 1 Besuki, SMAN 1 Panji, and SMAN 1 Kapongan. Seven teachers were then selected from the six schools using purposive sampling. These sites were selected because they met the characteristics preferred by the researcher, namely being equipped with adequate ICT technologies, including computers, projectors, and the Internet connection. In addition, all the schools are in a similar vein in providing such kind of technology support to serve teachers and students better with tools that can enhance the learning process. Such fulfillment of ICT technologies is very crucial in this study because it will minimize the emergence of the external factor influencing resistance to ICT integration. Schools adequate support of technology to teachers and students show their commitment in facilitating teaching and learning process. Therefore, as this factor is minimized, it was expected that the study could focus on exploring the teachers' own perception towards ICT that leads to their being resistant.

To collect verbal and non verbal data from the sources of data, interview, observation and documentation were used. The primary data were obtained by dominantly employing interview, which was also conducted first. In order to enhance the trustworthiness of the data, observation and documentation were also used following the interview. In this study interview as open-ended response was preferred for obtaining deeper understanding. According to Patton (1980, as cited in Hancock and Algozzine, 2006), the characteristics of this type of interview are that it has specific wording and sequence of questions which are predetermined (i.e. interview guide), that all participants are asked basic questions in the same order, and all questions require openended responses. The interview guide was developed based on the four indicators were taken from the summary of factors which might occur in the teacher's resistance to ICT integration, namely; 1) the teacher's belief towards the use of ICT in ELT, 2) pedagogic competence related to the use of ICT in ELT, 3) cultural dilemma regarding the shift of the teacher's role in the class, and 4) the teacher's ICT competence. The four indicators were further developed into six subquestions, as follows; 1) what belief does the teacher hold of ICT in ELT?; 2) what significances does ICT bring to ELT?; 3) what does the teacher do differently when integrating ICT in his/her EFL classroom?; 4) how does the teacher feel about the shift of roles in the class between $\mathrm{him} / \mathrm{her}$ as a teacher and the students when ICT is used?; 5) what changes does the teacher experience when integrating ICT in ELT?; and 
6) how well does the teacher operate ICT? Further, these subquestions were developed into 21 question items in total that can be seen in Appendix. Then, it is followed by observation and documentation. Since the case studied was the subject's resistance towards ICT integration, the researcher attempted to observe how the teacher taught in the class and interacts with ICT technologies provided in the school, as well as how s/he operated other ICT devices for daily use. The documents to be the data were all supportive documents, especially those used for teaching in the class like the lesson plans and text books.

\section{Result and Discussion}

Factors Contributing to EFL Teacher's Resistance in Integrating ICT in ELT

All subjects' different attitudes towards ICT integration have been revealed. First, there are two teachers who teach in well facilitated schools, in which LCD projectors are available all the time and the Wifi connection is mostly fine, are classified as not resistant at all. They have shown high interest in implementing ICT in the class as well as the willingness to learn more. In fact, they have employed a variety of software in the classroom activities and have instructed the students to employ it, too. For example, they use Movie Maker and Adobe Audition for creating video and dubbing because the teacher assigns them to record the process of making craft.

Furthermore, only one teacher who confesses that he hardly uses ICT in his teaching. His main and only reason is that he is a senior teacher who is about to retire in a couple years. At his age, according to him, it is very hard to try learning new things, particularly learning the ICT technology. He adds that the fact he is going to retire soon makes him reluctant to try new ways of teaching in his class; moreover, he thinks that the old ways of teaching are still appropriate to be implemented in the class. His teaching mostly depends on the given textbook and uses whiteboard to clarify his explanation to the students. This teacher is classified as an extremely resistant teacher.

Aside from the obviously resistant teacher, the other teachers, four teachers, have been revealed using ICT sometimes in their teaching. It is disclosed that they have positive views about it but they posses several negative attributes, too. In fact, it is surprising that these negative attributes indicate that these teachers are somewhat resistant to ICT integration in ELT. From the data obtained, the researcher sees a pattern and finally classifies three categories of resistance to ICT integration in ELT. In order to present the detailed process of revealing the pattern of resistance towards ICT in ELT, this chapter presents the detailed findings from every subject subsequently. Data from every subject will be presented anonymously in the following with only using codes as the identity. Therefore, there will be Subject 1, Subject 2, Subject 3, until Subject 7.

\section{Subject 1}

Subject 1 is the oldest of all subjects ( 57 years old). He showed that being an aged teacher was the salient factor for his resistance towards ICT integration in ELT, regardless the supporting ICT technologies in his school. It was observed that the subject prefers using the conventional way to teach although the school has provided ICT equipment for teaching. Besides, although Subject 1 realizes how ICT could have helped his teaching, he chooses to step back because he is concerned about failing again. The researcher interprets that Subject 1 is a pessimistic teacher because he did not look comfortable when talking about ICT integration. Moreover, when it came to the discussion about the teaching practice and he recommended that the researcher talk to Subject 2 about it. From the subject's reaction, the researcher considers that this might be more than just the matter of age; 
unwillingness to learn might contribute to this form of resistance of integrating ICT in the English teaching.

Viewing Subject 1 from his degree of resistance, he is very resistant to ICT integration. Although he is aware that the technology nowadays has advanced, he is not encouraged to learn it. He is still comfortable teaching using the conventional method, which is using whiteboard and lecture most of the time. What he believes as a form of ICT integration in his class is that he allows his students to use their smartphones in the class to do the task and informs his students the web page they can visit to improve their English skill. However, this does not show any significant improvement in his students' performance. It was found in the classroom observation that they could not complete the task accordingly and they looked not really eager to learn. This could be an indicator for low learning autonomy. It means that Subject 1 should have been aware of the unachieved learning goals in his class.

\section{Subject 2}

Subject 2 is has a slightly different variable with Subject 1 . She is at her forties, younger than Subject 1. The researcher sees that Subject 2 has positive belief towards ICT and that she is open to the consequence when a teacher is no longer the source of information because of the existence of the Internet. She also possesses good knowledge of pedagogy because she shows some understanding of how to improve the students' skill. She somehow becomes resistant towards ICT integration in her class because she thinks that allowing the students to use ICT will expose them to inappropriate content in the Internet. Despite her positive belief towards ICT in ELT, Subject 2 is resistant to improve her use of ICT in the class because she thinks that her current use of ICT has already contributed to make her students become more motivated in learning, although she is not confident whether ICT can improve her students' achievement. Besides, she also thinks that she lacks ICT competence that she still cannot perform more sophisticated uses of ICT for teaching purposes although she is aware that ICT can help teachers become more creative in designing the class. Therefore, though she makes her attempt to learn, this may not run smoothly. There are also other external ICT problems found to be discouraging, like troubles with the electricity and Wifi connection.

It was evident that the teaching practice of Subject 2 integrates more ICT than that of Subject 1. Subject 2 uses PowerPoint slides to help her explain the learning material to her students. She also sometimes uses audio and video in her teaching to enhance students' comprehension. However, it is a bit disappointing when she teaches using almost the same as the conventional method. She still uses teacher's explanation to deliver the learning material and uses the PowerPoint slides as the substitute for her whiteboard. It is also revealed that her students' English skills are not improved very significantly although she integrates ICT in her class. This shows that she integrates ICT less maximally and does not seem to focus the learning on learners.

\section{Subject 3}

From Subject 3, the researcher identifies similarities of ICT uses in the English classes between this subject and Subject 2, such as the belief towards ICT in ELT, the openness to ICT as another source of information and the practices of ICT integration. Both of the subjects have positive thought that ICT is helpful for both teachers and students in English teaching. They are also employing the student centered in the classroom and allow their students to learn from the Internet. Meanwhile, the practices of ICT integration include presentation slides, audios, videos, pictures, and games, whereas, she has been aware of more sophisticated uses of ICT in ELT, like the use of several programs that enhance 
students' independent learning. Therefore, the attitude of resistance is identified. Subject 3 , in fact, has become aware of her resistance that she stated her main problem of not integrating the more sophisticated use of ICT is her inability. She has lack of ICT competence for teaching purposes. She thinks that her current uses of ICT are enough to help her students participate in the learning activities more actively. Sometimes, she is also troubled with a tiring procedure to use LCD projector in her class when she wants to use ICT. Therefore, so far the factors of resistance towards ICT integration in ELT identified by the researcher still stand, namely the age of the teacher, the teacher's lack of ICT competence, the satisfaction with the achievement of their current uses of ICT in the class, the concern about the possibility that ICT can mislead the students, and the unsupportive school facilities.

It is true that she has been aware of her resistance, but she has optimized the integration of ICT in her class. For example, she uses PowerPoint to make an interactive game because PowerPoint is what she thinks she knows a lot, although the game does not run well. Using ICT in her class has made her students eager to learn. Although she cannot see whether this is significant or not for improving her students' skills, she has identified that her students have developed a strategy in learning English.

Subject 4

As the youngest of all subjects, the researcher expects better performance of ICT integration in ELT from Subject 4. Moreover, she has recounted her experience to the researcher in designing an English learning game and in creating a blog which the preceding subjects have not known. Additionally, she has positive belief about ICT in ELT and she is pleased with ICT as the new source of information. In fact, the uses of ICT in Subject 4's classes are similar to those of Subject 2 and 3's. She has used PowerPoint to present her explanation in slides, audio and video players, and images to help her describe the learning materials. Whereas in her young age, she has the energy and the chances to improve her teaching practice in the class more than her older colleagues. Then, despite her knowledge of ICT, she still cannot determine how ICT is related to ELT; this proves her lack of pedagogical knowledge related to ICT use in ELT. Additionally, she is concerned about her students' being dishonest in completing the task, such as copying texts from the Internet, thus they might not learn the material well.

Briefly, the researcher almost comes to the conclusion that the age of a teacher does not matter in the integration of ICT in ELT; still, more data are needed to make this finding saturated. Aside from the age factor, the researcher finds that resistance can also be caused by the teacher's lack of pedagogical competence of integrating ICT into learning. Because the teacher fails to understand how ICT is useful to help improve the students' English skills, she cannot drive herself to maximally use ICT for the purpose of English teaching. It seems that she is unwilling to learn and use ICT more. Finally, the researcher adds evidence to the factor of concern about the students, that the teacher thinks ICT will expose learners to ready-to-use texts thus leads to the phenomenon of copying and pasting work from the Internet. Up till collecting and analyzing the data from Subject 4, the researcher cannot prove any of the factors is worth elimination yet but she adds another factor of lacking pedagogical competence.

The researcher views Subject 4 as a teacher who is reluctant to optimize her ICT integration in her class by maximizing her capabilities and opportunities. In her practice, ICT is used as a tool to efficiently interact with her students without her having to move from her seat. She believes that using ICT can make her students focus on the learning better because they can see the presentation on the wall. Therefore, the less optimized use of ICT in the class might contribute to her students' inability 
to significantly enhance their language skills.

\section{Subject 5}

Subject 5 is reaching his 50 s. The school where he is teaching now is one of the favorite schools in Situbondo that every year many graduates of junior high school compete in the entry test to get accepted in this school. This school is well equipped; Wifi connection is available and LCD projector is installed well in every class. There are $37 \mathrm{LCD}$ projectors in the school; 30 are installed in every class, five are put in the laboratories, and two are put in the office. There is also a language lab in the school which is used by all classes in exchange. This school has very different characteristics from previous schools.

Subject 5 has left positive impression to the researcher because he is a kind of teacher who learns hard and fast. Despite his being a senior teacher who has taught almost 20 years, he can follow the advancement of ICT quite well. This is probably supported by the ICT technologies in the school and his willingness to learn. He has shown his understanding of using ICT appropriately to enhance the students' skills that integrating ICT should suit the students' needs in the class. Supported by his use of ICT in the class, his students are more comfortable and eager to learn. They show their interest in learning by independently learn the material outside the classroom. In brief, the data from Subject 5 seem to not affect the previous findings of the resistance factors because he is barely resistant to ICT integration in his class and his practice in the class is effective to enhance the students' learning autonomy.

\section{Subject 6}

Subject 6 is at her 50 's. She teaches in a school that has similar characteristics with the school of Subject 5 . She is also very familiar with ICT. She has been using ICT, especially an android tablet, for not only online chatting but also for keeping notes from meetings. This attitude is superior to other subjects because she can maximally use her devices for multiple purposes. Meanwhile, for teaching purposes, she is using ICT like PowerPoint, playing audios and videos, displaying pictures, and running several more sophisticated programs like Quipper.com, Movie Maker, and Adobe Audition. She has admitted that she has not faced a problem; in fact, she feels helped. When her students find difficulties and ask for more explanation, she instructs them to search in the Net first. She also has noted that the students' achievement is improved and they also develop their own learning strategy more autonomously. However, because sometimes the Wifi connection is not always good, especially for classes in the back, her students have to have data quota, just in case they need to search for something in the class.

Subject 6 barely shows resistance to ICT integration in ELT. In spite of the fact that she is an aged teacher, Subject 6 has shown high interest and maximum uses of ICT in her class. She is also confident that she has the competence to run ICT equipment in her class. Moreover, she is supported by the school which has completed the classes with LCD projectors thus they are always available for use.

\section{Subject 7}

Subject 7 is at his 30 's. He has started teaching as an honorary teacher in an elementary school soon after he graduated from his undergraduate study in Malang and moved to this senior high school after two years. In the school where he is teaching, there are $19 \mathrm{LCD}$ projectors provided and Wifi connection in hotspot area. However, none of the LCDs is installed in classrooms because of security concern. Therefore, teachers and students have to go on a certain procedure of using the LCD for learning. The subject himself has admitted that he is not very fluent in operating ICT technologies.

It is concluded from Subject 7 that he 
has similar characteristics with Subject 2, 3, and 4 . He has positive views about ICT in ELT and he welcomes the new wave of information sources in the Internet. However, though he knows what is best to give to his students he is still reluctant to achieve it. In his attitude of being resistant to ICT integration in the class, there are several factors which are found. First, the school does not support the teaching using ICT because there is not LCD projector installed in the classrooms. Next, he lacks the competence of how to best integrate ICT into teaching, that he shows a lack of confidence thus barely integrates it to English teaching; (2) moderate resistance, the teacher who accepts ICT and uses it for English teaching but still has concerns about using it; and (3) zero resistance, the teacher who shows almost non-resistant attitude towards ICT integration in ELT. These categories are presented along with their factors found in the study, and based on the obtained data from every subject, the researcher decides that each of the subject can be included to the three categories, which can be seen in details in Table 2 .

Table 2. Categories of Resistance to ICT Integration in ELT

\begin{tabular}{|c|c|c|}
\hline Extreme Resistance & - $\quad$ Subject 1 & $\begin{array}{l}\text { - } \quad \text { Lack of ICT competence } \\
\text { - Unwillingness to learn } \\
\text { - } \quad \text { Unwillingness to use }\end{array}$ \\
\hline Moderate Resistance & $\begin{array}{ll}\text { - } & \text { Subject } 2 \\
\text { - } & \text { Subject } 3 \\
\text { - } & \text { Subject } 4 \\
\text { - } & \text { Subject } 7\end{array}$ & $\begin{array}{l}\text { - Concerns that ICT can mislead students } \\
\text { - Unsupportive school facilities } \\
\text { - Lack of pedagogical knowledge related to } \\
\text { the integration of ICT in ELT } \\
\text { - Lack of ICT competence }\end{array}$ \\
\hline Zero resistance & $\begin{array}{ll}\text { - } & \text { Subject } 5 \\
\text { - } & \text { Subject } 6\end{array}$ & 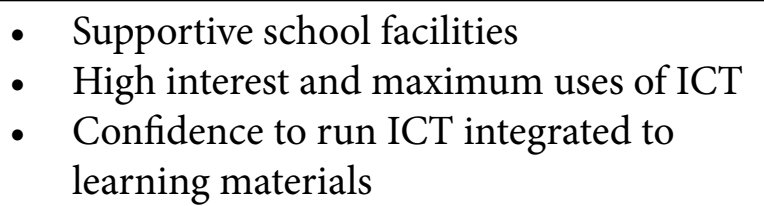 \\
\hline
\end{tabular}

in integrating ICT. In addition, he lacks ICT competence, as he admitted that there are many things he has not been able to do yet. Moreover, this can be caused by his reluctance due to the fact that he has some other responsibilities to fulfill in the school.

Up to this point, it is found that the data are all saturated because there is not a new factor emerging from the subjects under study. The final findings are put into three categories of resistant teachers which show their levels of reluctance to ICT integration in ELT. They are: (1) extreme resistance; the teacher who is denying the presence of ICT

\section{Models of Teaching for Resistance Categories}

The different practices of ICT integration in ELT by the three aforementioned categories happen because of the different other variables namely presage variables and context variables (Stern, 1983). Stern mentions in his book a model of teaching that was developed by Dunkin and Biddle in 1974 distinguishing four main categories of variables, which are presage, context, process, and product.

Presage variables include the teacher's characteristics, both as an individual or as a group, that are brought to the class. In this 
study, these variables include the teacher's characteristics, which are their beliefs towards ICT integration in ELT, openness to ICT as another source of knowledge in the classroom, and their ICT competence and pedagogical knowledge related to it. Meanwhile, context variables deal with 'the conditions within which the teacher must operate. This study specifically includes the context of the school support of ICT for ELT, like the availability of LCD projectors and Wi-fi connection for of English language teaching. The practices that have been identified in this study are the uses of ICT in ELT, which are found to be different in every category of resistance. The different practices result in different results in the last variable, which is product variable. The product variable includes the students' achievement in their English classes. The differences among the three categories are depicted in Figure 1, Figure 2 and Figure 3.

\begin{tabular}{|c|c|}
\hline $\begin{array}{l}\text { PRESAGE VARIABLES } \\
\text { Teacher's belief towards } \\
\text { The teacher is not su } \\
\text { English skills } \\
\text { Teacher's openness to the } \\
\text { knowledge in ELT }\end{array}$ & \begin{tabular}{|l|} 
PROCESS VARIABLES \\
Teacher's use of ICT in the class: \\
- The teacher does not in- \\
tegrate ICT into English \\
teaching \\
He allows the students to use \\
mobile phone for search- \\
ing unfamiliar words and \\
information, and electronic \\
dictionaries \\
Student's behavior towards ICT \\
integration in the class \\
- They interact well with ICT
\end{tabular} \\
\hline
\end{tabular}

Figure 1. The Model of Teaching for Extreme Resistance Category

students and teachers. The next variable is process variable which is the central focus of the model. This variable collects the presence of the teacher and the students in the practice
Dealing with the Resistance

The characteristics of ICT, that is making information and communication 


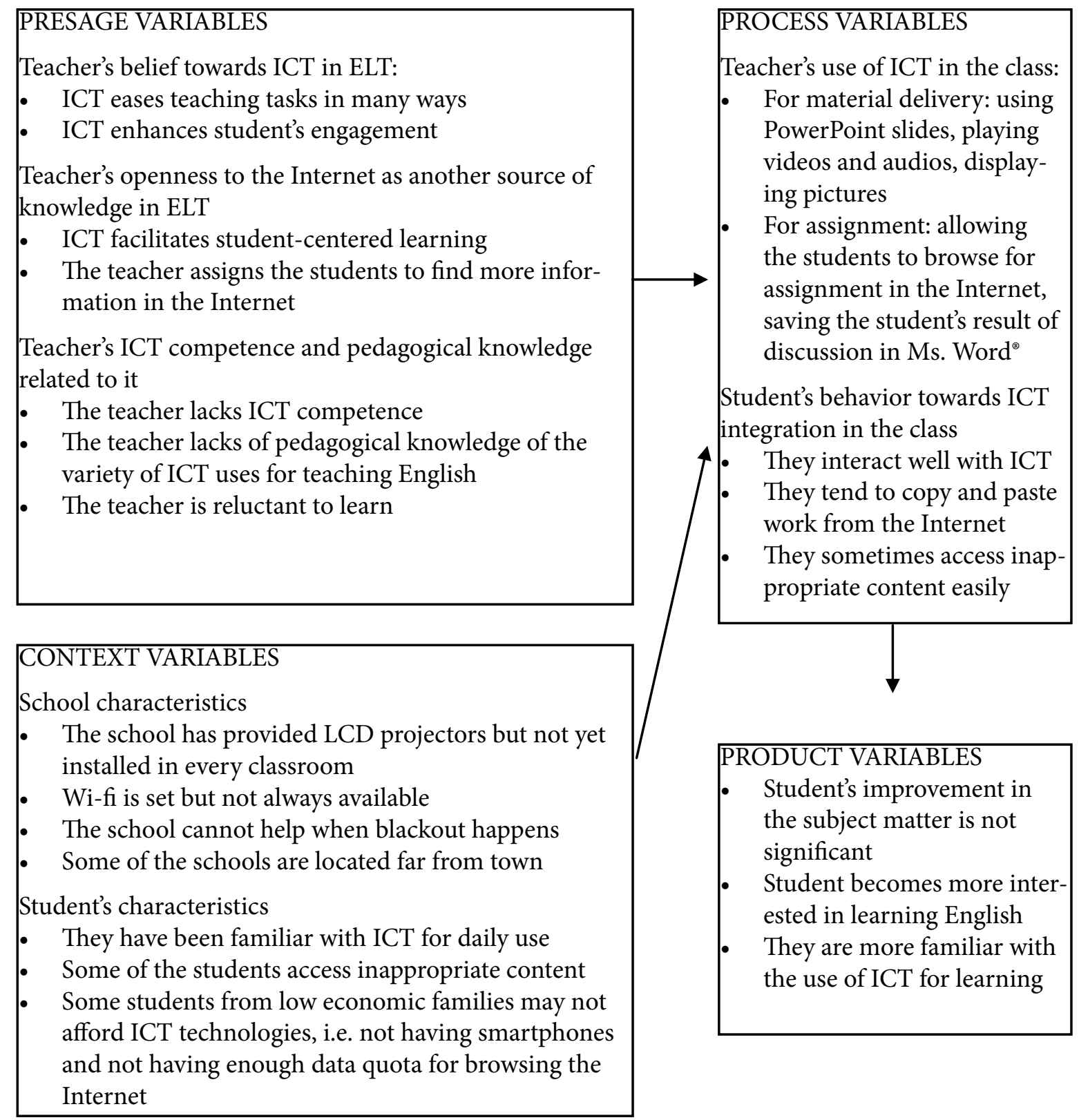

Figure 2. The Model of Teaching for Moderate Resistance Category

accessible and very handy, offers benefits for EFL teachers and students. These have been discussed in previous chapters and sections; generally ICT makes it possible for teachers to experience easier and faster ways of preparing the learning materials. Teachers can both browse for more authentic materials in the Internet and keep them in their computers as their inventory. As for students, on the other hand, ICT can improve their motivation to learn English because it allows for more independent and autonomous learning, which is the goal for language teachers (Healey, 2002). Therefore, since ICT provides more benefits for teaching and learning process, the achievement of autonomous learning should be accomplished more easily by integrating it into teaching.

Knowing that ICT technologies can enhance language learners' skills, and that they have been more affordable for students and teachers nowadays, ELT should have shown the 


PRESAGE VARIABLES
Teacher's belief towards ICT in ELT:
ICT eases teaching tasks in many ways
ICT enhances student's engagement
Teacher's openness to the Internet as another source of
knowledge in ELT
- ICT facilitates student-centered learning
The teacher assigns the students to find more infor-
mation in the Internet
Teacher's ICT competence and pedagogical knowledge
related to it
The teacher lacks ICT competence
The teacher lacks of pedagogical knowledge of the
variety of ICT uses for teaching English
The teacher is reluctant to learn

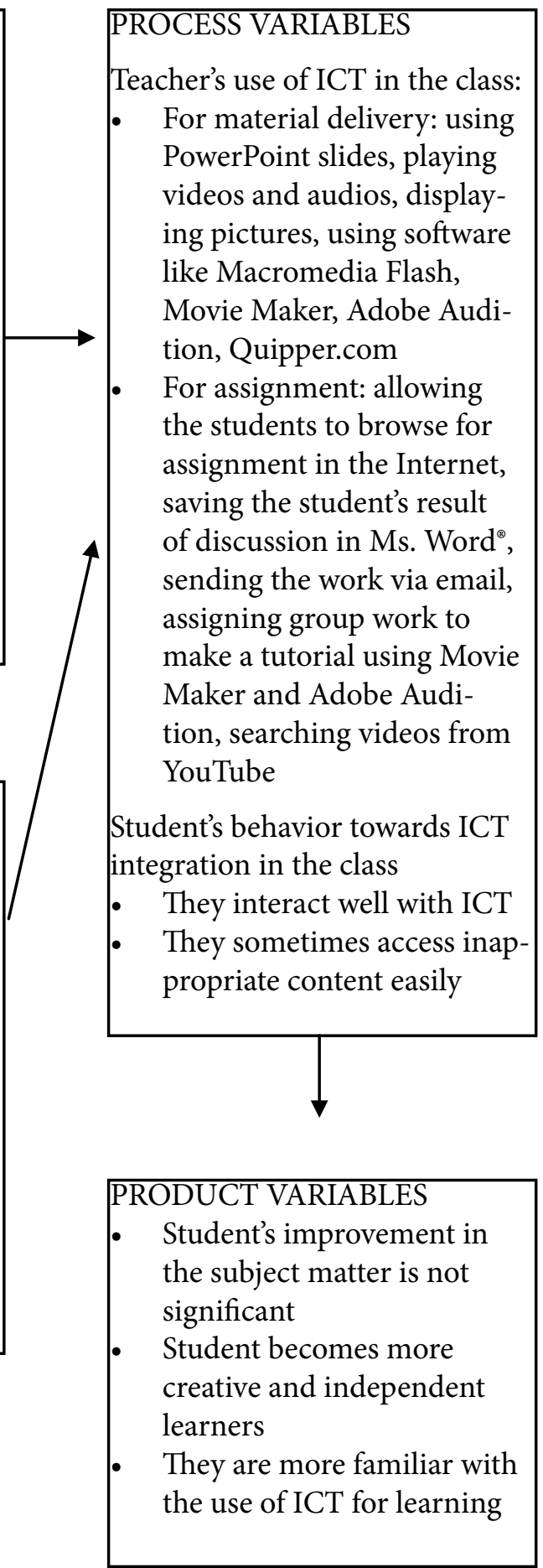

Figure 3. The Model of Teaching for Zero Resistance Category

achievement of the advantages in integrating ICT, i.e. the students' independent learning. The students should be able to independently find their preferred strategies by using the technology for improving their language skills. However, this was not found in the present study. Most of the English teachers admitted that they could raise their students' interest to learn English, but none of them had mentioned the significant increase in their skills. The most salient differences between classes that are integrated with ICT and those which are 
not are seen in four most uses; (1) PowerPoint slides as the substitute for whiteboard; (2) audio and video as the substitute for talks; (3) Google Translate and electronic dictionaries as the substitute for book dictionaries; and (4) the Internet as the substitute for textbook and teacher's explanation. In fact, such form of substitution is what Hanover Research (2014) underlines. It is mentioned that this way of integrating ICT will likely reinforce conventional teaching, not student centered learning. In addition, when ICT is used this way, the students will "be distracted by the tools, but they are not engaged in the content. This should be the concern of English teachers when integrating ICT. ICT is supposedly used as learning media that enhances learning, not as a tool that eases teachers' job in the class only.

Kumaravadivelu (2003) has given notable contributions towards language instruction, especially through his 10 macrostrategies within which language teachers are guided to design meaningful and effective teaching. For the purpose of this study, the discussion refers to the fourth macrostrategy, which is promoting learner autonomy. Teachers are supposed to understand the learner's characteristics and preferences, especially those that are affected by the Information Age. The learners nowadays are considered digital natives because they can easily adapt with the advanced technology. Therefore, understanding it should make teachers more encouraged to keep up and fulfill the demand for the language learning since they are the main controllers in the class. Learner-centered learning should be enhanced by giving meaningful tasks that can trigger their independence. This can be done by teaching them learning strategies so that the students will get the push for being autonomous. In other words, the presence of ICT technology should not be merely replacements of the manual tools like whiteboard to PowerPoint slides, neither should it be the false chances that the teachers use to remain more passive in the class than when employing the conventional teaching.

\section{Conclusion}

The presence of ICT within the range of English language teaching has brought advantages. It can enhance independent learning, arouse motivation and interest in learning, promote intercultural interaction, and develop learning sources for specific purposes. Despite that, there are three categories of resistance discovered in this study, namely extreme, moderate and zero resistance. Besides, this study has also found two important conclusions from the study, which are about age and the inconsistency between perception and practice.

Age may not be a true determiner for an EFL teacher's use of ICT in the class. Based on the study findings, it is not completely true that the older teachers will integrate lesser technology into their teaching practice because they are less competent than the younger teachers. It has something to do with their professional development. Fulfilling the challenges requires the teachers' willing to learn more and do more than their skills. Additionally, inconsistency between the teacher's perception towards the integration of ICT in ELT and their practice in integrating it was found. Regardless their positive views, the practice reflects it negatively. It was revealed that not all of the teachers performed effective integration of ICT in the class which can enhance teaching and learning process. This is caused by their lack of ICT competence and pedagogical knowledge. In fact, many of the teachers are aware of their lack but unwilling to improve their teaching practices. Again, the teacher's willingness is a more powerful force in the ICT integration than the teacher's perception.

By realizing the importance to integrate ICT into ELT nowadays and the need for teacher professional development, this study implies that working more on making the teachers willing to improve their practice is more important. The teachers' age or competence in operating the technologies should not be the parameter to judge their 
actual use of ICT in the class. The use of ICT in the class should focus more on the achievement of the shared goal of learning in ELT and the curriculum, which is shaping autonomous learners. This will make the ICT integration more effective and appropriate.

\section{References}

Benson, P. (2015). Commenting to Learn: Evidence of Language and Intercultural Learning in Comments on YouTube Videos. Language Learning and Technology, 19(3), 88-105.

Bingimlas, K. A. (2009). Barriers to the Successful Integration of ICT in Teaching and Learning Environments: A Review of the Literature. Eurasia Journal of Mathematics, Science \& Technology Education, 5(3), 235-245.

Bogdan, R. C., \& Biklen, S. K. (1992). Qualitative Research for Education: An Introduction to Theory and Methods (2nd ed.). MA: Allyn and Bacon.

Cahyani, H., \& Cahyono, B. Y. (2012). Teachers' Attitudes and Technology Use in Indonesian EFL Classrooms. TEFLIN Journal, 23(2), 130-148.

Çelik, S., Arkın, E., \& Sabriler, D. (2012). EFL Learners' Use of ICT for Self-Regulated Learning. The Journal of Language and Linguistic Studies, 8(2), 98-118.

Hancock, D. R., \& Algozzine, B. (2006). Doing Case Study Research: A Practical Guide for Beginning Researchers. New York: Teachers College Press.

Hanover Research. (2014). Professional Development for Technology Integration.

Harendita, M. E. (2013). Why Resist? A Closer Look at Indonesian Teachers' Resistance to ICT. International Journal of Indonesian Studies, 1, 41-57.

Hashemyolia, S., \& Ayub, A. F. M. (2014). The
Effects of Utilizing English Language Courseware on Secondary School Students' Performance in Iran. Journal of Educational and Social Research, 4(3), 71-78. doi: 10.5901/jesr.2014.v4n3p71

Healey, D. (2002). Learner Autonomy with Technology: What Do Language Learners Need to be Successful? TESOL 2002, CALL-IS Academic Session.

Hennessy, S., Ruthven, K., \& Brindley, S. (2005). Teacher Perspectives on Integrating ICT into Subject Teaching: Commitment, Constraints, Caution and Change. Journal of Curriculum Studies, 37(2), 155-192.

Jin, S. (2015). Using Facebook to Promote Korean EFL Learners' Intercultural Competence. Language Learning and Technology, 19(3), 38-51.

Kumaravadivelu, B. (2003). Beyond Methods: Macrostrategies for Language Teaching. New Haven, CT: Yale University Press.

Mokoginta, K. (2013). Student-Centered Learning (SCL) Approach in EFL Classes. Bahasa dan Seni, 41(2), 239-247.

Nair, G. K. S., Rahim, R. A., Setia, R., Husin, N., Sabapathy, E., Mohamad, R., . . . Jalil, N. A. A. (2012). ICT and teachers' attitude in English language teaching. Asian Social Science, 8(11), 8-12.

Orlando, J. (2014). Veteran Teachers and Technology: Change Fatigue And Knowledge Insecurity Influence Practice. Teachers and Teaching: Theory and Practice, 20(4), 427-439.

Pacific Policy Research Center. (2007). 21st Century Skills for Students and Teachers. Honolulu: Kamehameha Schools

Rababah, L. M., Melhem, N. Z. B., Jdaitawi, M. T., Rababah, B. S., \& Rababah, O. M. (2012). EFL Teachers' Barriers to the Use of ICT in Instruction in Jordan. Paper presented at the First International 
Conference on Behavioural and Social Science Research, Universiti Tunku Abdul Rahman, Kampar, Perak, Malaysia.

Raval, D. M. R. (2014). Use of ICT in English Language Teaching. International Journal of Research in all Subjects in Multi Languages (IJRSML), 2(21-24).

Salehi, H., \& Salehi, Z. (2012). Integration of ICT in Language Teaching: Challenges and Barriers. Paper presented at the 3rd International Conference on e-Education, e-Business, e-Management and e-Learning, Singapore.

Stern, H. H. (1983). Fundamental Concepts of Language Teaching. Oxford: Oxford University Press.

Tapaliya, M. P. (2014). English Teachers' Perception and Practices of Information and Communication Technology (ICTs) in Kathmandu District, Nepal. International Journal of Academic Research in Education and Review, 2(10), 251-258. doi: 10.14662/IJARER2014.056

Tinio, V. L. (2003). ICT in Education. New York: E-Primers.

Varank, I. \& Tozoglu, D. (2006). Why are Teachers Resistant to Change? Key Issues and Challenges in Technology Integration. Afyon Kocetepe Universitesi Sosyal Bilimler Dergisi, 8, 193-207.

Williams, M., \& Burden, R. L. (1997). Psychology for Language Teachers: a Social Constructivist Approach. Cambridge: Cambridge University Press.

Young, S. S. C. (2003). Integrating ICT into Second Language Education in a Vocational High School. Journal of Computer Assisted Learning, 19, 447-461. 
